\title{
INVESTIGATION OF THE EFFECT OF ROBOT WAITER USAGE DESIRE ON WORD OF MOUTH COMMUNICATION AND ROBOT WAITER USAGE ATTITUDE IN RESTAURANTS
}

\author{
RESTORANLARDA ROBOT GARSON KULLANIM ARZUSUNUN, AĞIZDAN AĞIZA \\ İLETIŞIM VE ROBOT GARSON KULLANIM TUTUMU ÜZERINNDEKİ ETKİSININ \\ ARAŞTIRILMASI
}

İbrahim AYDIN $^{1}$

\begin{abstract}
Robots, which are a reflection of technological developments, are used instead of human waiters for a more effective and efficient workforce and less service failure. This study aims to investigate the effect of robot waiter usage desire on word of mouth (WOM) communication and robot waiter usage attitude of customers in restaurants. In the study, the direct effect of robot waiter usage attitude on WOM and the indirect effect of robot waiter usage desire (through robot waiter usage attitude) on WOM were also investigated. The sample of the study consists of 316 people living in Turkey. The sample of the study was reached by an online survey and snowball sampling method. Structural equation modeling was used in the analysis of the obtained data. According to the results obtained from the study, the desire to use the robot waiter has a direct positive effect on the attitude of using the robot waiter and WOM. In addition, the desire to use attitude robot waiter has an indirect and positive effect on WOM (through the use of robot waiters). It has also been concluded that the use of robot waiters has a direct positive effect on WOM. The fact that the desire to use the robot waiter has a positive effect on both the robot waiter usage attitude and WOM has shown that the creation of the robot waiter usage desire is very important for the restaurants. It is thought that effective use of marketing communication activities will be beneficial to create the desire to use a robot waiter.
\end{abstract}

Key Words : Robot Waiter, Usage Desire, Word of Mouth Communication

Jel Classification : M30, M31

$\ddot{O} z$

Teknolojik gelişmelerin bir yansıması olan robotlar, insan garsonların yerine daha etkin ve verimli işs gücünün elde edilmesi, daha az hizmet hatasının meydana gelmesi amaçlarıla kullanılmaktadır. Bu çalışmanın amacı restoranlarda robot garson kullanım arzusunun, ăgızdan ăğza iletişim ve müşterilerin robot garson kullanım tutumu üzerindeki etkisini araştırmaktır. Çalışmada robot garson kullanım tutumunun ă̆ızdan ă̆ıza iletişim üzerindeki doğrudan etkisi ve robot garson kullanım arzusunun, robot garson kullanım tutumu aracılı̆̆ıla ağızdan ağıza iletişim üzerindeki dolaylı etkisi de araştırılmıştır. Çalışmanın örneklemini Türkiye'de yaşayan 316 kişi oluşturmaktadır. Çalışmanın örneklemine online anket ve kartopu örnekleme yöntemiyle ulaşılmıştır. Elde edilen verilerin analizinde yapısal eşitlik modellemesi kullanılmıştır. Çalışmadan elde edilen sonuçlara

\footnotetext{
${ }^{1}$ Dr. Ögr. Üyesi İbrahim Aydın, Van Yüzüncü Yıl Üniversitesi, Erciş İşletme Fakültesi, İşletme Bölümü, aydnibrhm@hotmail.com, ORCID: 0000-0002-0720-364X
} 
göre, robot garson kullanım arzusunun, robot garson kullanım tutumu ve ă̆ızdan ă̆ıza iletişim üzerinde doğrudan olumlu etkisi bulunmaktadır. Ayrıca robot garson kullanım arzusunun, robot garson kullanım tutumu aracılığıyla ă̆ızdan ă̆ıza iletişim üzerinde dolaylı ve olumlu etkisi bulunmaktadır. Robot garson kullanım tutumunun ă̆ızdan ă̆ıza iletişim üzerinde doğrudan olumlu etkisi olduğu sonucuna da ulaşılmıştır. Robot garson kullanım arzusunun hem robot garson kullanım tutumu hem de ă̆ıdan ağıza iletişim üzerinde olumlu etkisinin olmasl, robot garson kullanım arzusunun oluşturulmasının restoranlar için oldukça önemli olduğunu göstermiştir. Robot garson kullanım arzusunun oluşturulması için pazarlama iletişimi faaliyetlerinin etkin şekilde kullanılmasının faydalı olacă̆ düşünülmektedir.

Anahtar Kelimeler

Jel Kodlar

\section{INTRODUCTION}

Today, society is living a life increasingly more and more influenced by technological developments, and technological developments have the potential to enter every field in daily life. The robotics field is developing rapidly, with new robots being designed and manufactured every day by companies and research institutions around the world. These new developments gradually fill the technological gaps and offer new market opportunities (Garcia-Haro et al., 2021: 18). Thanks to the modernization in robot technology, many new designs and mechanisms that can read human thoughts and understand their movements have been created (Asif et al., 2015: 1). Some robots have been designed to help and serve people with physical and social interactions (Ivanov et al., 2017: 1503). Such robots find wide application in helping and serving humans. One of these areas is the use of robot waiters in restaurants (Asif et al., 2015: 1-2). Because it is known that the work of waiters in restaurants is difficult (Hamdany et al., 2019: 2486). Service efficiency in the food and beverage industry is improving with the advances in robot technology (Hwang et al., 2021: 263). Robot waiters can perform numerous tasks, from serving food and beverage to taking orders while walking around the restaurant (Garcia-Haro et al., 2021: 12). While an average human waiter can serve 200 meals a day, a robot waiter can serve 300-400 meals (Hospitality \& Catering News, 2019). Robotic waiters don't make mistakes with repetitive tasks and have no trouble carrying heavy meals (LondonlovesBusiness, 2019). The reduction in labor costs (Hwang et al., 2020a: 272) is another advantage in the use of robot waiters. Considering these characteristics of robot waiters, we can define robot waiters as follows: "They are robots that interact with customers in restaurants, communicate, provide waiter service effectively and efficiently, and do not make human-induced service failures."

The aim of this study is to investigate the effect of robot waiter usage desire in restaurants on WOM and robot waiter usage attitude. No research has been found investigating the effects of the desire to use a robot waiter on WOM. With this unique aspect of the study, it is expected that to fill a gap in the literature as well as it will make significant contributions to the literature and the business world. 


\section{LITERATURE AND HYPOTHESES}

\subsection{Word of Mouth Communication (WOM)}

Consumers naturally talk among themselves about goods, services, brand promotion activities, and the meanings that the brand evokes in people. Customers, potential customers and even noncustomers exchange information without any influence or direction from the brand owner (Fill and Turnbull, 2016: 50). People exchange information about products is called WOM (Dülek and Aydın, 2020: 272). WOM can have a substantial impact on consumers' purchasing behavior. For consumers, the words and recommendations of trusted friends, family, colleagues, and other consumers are more reliable than information from commercial sources such as advertising and salespeople (Kotler et al., 2018: 163). Besides, since WOM is seen as a reliable source of information, it is the strongest and most accurate source of information for consumers (Kerin and Hartley, 2017: 138). WOM is an important factor in establishing, developing and maintaining customer relations (Pride and Ferrell, 2019: 290). Potential customers are reached through WOM and the perceived value of existing customers towards the company becomes stronger, and while these happen, no cost element occurs for the company (Grewal and Levy, 2017: 228). One of the advantages of positive WOM for companies is that it is increasingly effective in positioning the brand (Dibb and Simkin, 2013: 214). In the light of this information, it is understood how important WOM is for companies. Studies investigating the effects of robot waiter usage desire and robot waiter usage attitude on WOM are given under the following headings.

\subsection{Robot waiter Usage Desire}

Perugini and Bagozzi (2004: 71) defined desire as: "A state of mind whereby an agent has a personal motivation to perform an action or to achieve a goal." Studies of the effects of desire on WOM are given below.

Considering that WOM mechanisms act similarly to electronic WOM (Gruen et al., 2006), the effects on electronic WOM will also be taken into account when the studies in the literature are examined. In their study with 226 samples, Wen-Hai et al., (2019) concluded that the desire for revenge, which is the result of negative emotions such as anger and regret caused by defects or deficiencies in new products, will cause the negative WOM. According to this result, when the variables are read backward, it is expected that the desire to use, which is a positive emotion towards robot waiters, will cause the positive WOM. In their study, Hennig-Thurau et al., (2004) concluded that consumers' desire for social interaction and economic incentive desires lead to electronic WOM behavior. Lee et al., (2013) stated that the desire to share information and the desire to promote oneself have a direct positive effect on electronic WOM in the results they obtained by using qualitative and quantitative research methods together. Parry et al., (2021), as a result of a survey conducted with 618 Japanese mothers who buy products produced to protect the health and safety of children, concluded 
that the desire to establish social bonds is positively related to the WOM. Considering these results, it can be said that the desire to use robot waiters will have a positive effect on WOM

\subsection{Robot Waiter Usage Attitude}

"Attitudes are mental and neural representations, organized through experience, exerting a directive or dynamic influence on behavior." (Breckler and Wiggins, 1989: 409). Marketers should understand consumers' attitudes in various situations and find ways to influence these attitudes to make consumers adopt more positive attitudes towards the goods or services offered (Kapoor and Madichie, 2012: 87). The following studies were examined to understand the effects of robot waiter usage desire, which is among the aims of the study, on robot waiter usage attitude.

Hwang et al., (2019a) concluded that there is a positive relationship between attitude and desire in their study on drone food delivery services, in which 320 people participated. As a result of their study on 320 airline passengers, Hwang and Lyu (2020) concluded that the desire for environmentally friendly airline transportation has a positive effect on customer attitude. Kang and Kim (2012) in their study with the data obtained from 301 students, concluded that the desire for consumer products has a positive effect on the attitude towards consumer-specific clothing in the electronic environment. Hwang et al., (2020b) in their study conducted with data collected from 418 people in South Korea, concluded that there is a positive relationship between attitude and desire towards robotic restaurants. As a result of these results, it is expected that the desire to use the robot waiter will have a positive effect on the attitude of using the robot waiter.

To understand the effects of robot waiter usage attitude on WOM, the following studies were examined.

Foroudi et al., (2021), in their study, concluded that the attitude towards the brand positively affects WOM as a result of the data obtained from 464 restaurant customers. According to the results of the study conducted by Jalilvand et al., (2012) with the participation of 264 people, electronic WOM has a positive relationship with tourists' attitudes towards the destination. Baber et al., (2016) in their study conducted with the data obtained from 251 internet users, concluded that electronic WOM has a positive relationship with the attitude towards purchasing products from the internet. According to the results obtained from the study of Albarq (2014), there is a positive relationship between electronic WOM and tourists' attitudes to visit Jordan. Within the framework of these results examined, it is expected that the attitude of using robot waiters in restaurants will have a positive effect on WOM.

In the light of the information given above, the following hypotheses have been developed:

H1: The desire to use robot waiters in restaurants has a direct positive effect on WOM. 
H2: The desire to use robot waiters in restaurants has a direct positive effect on the attitude of using robot waiters.

H3: The use attitude of robot waiters in restaurants has a direct positive effect on WOM.

H4: The desire to use robot waiters in restaurants has an indirect positive effect on WOM through robot waiter usage attitude.

Considering the study hypotheses, the model of the study is given in Figure 1 below.

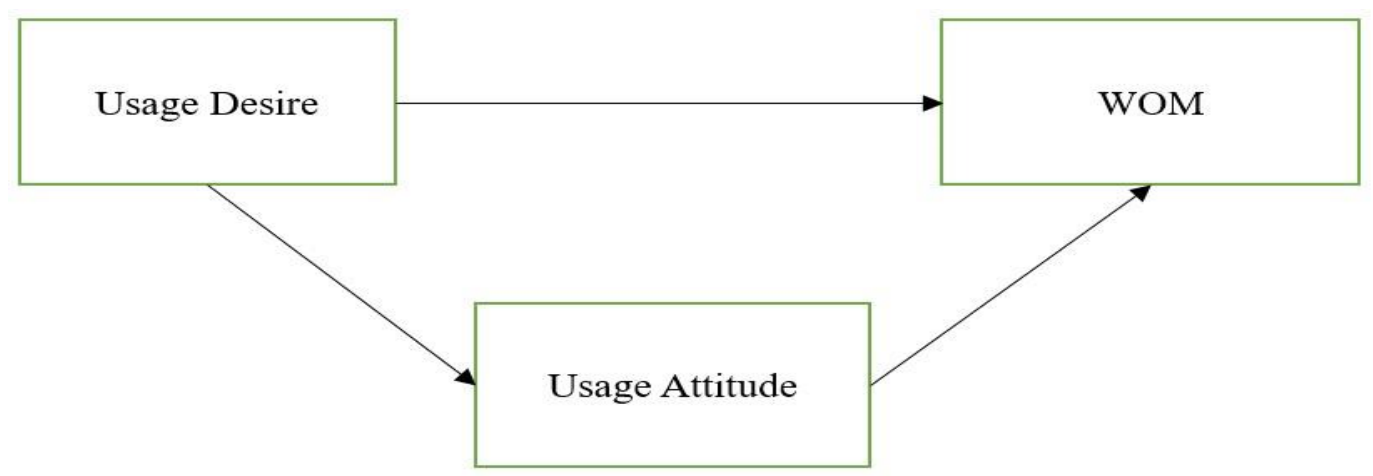

Figure 1. Conceptual Model

\section{METHODOLOGY}

\subsection{Data Collection Tools and Data Collection Process}

In the study, robot waiter usage desire, robot waiter usage attitude and WOM scales were formed as a five-point Likert scale. Scales used by Hwang et al., (2020b) for robot waiter usage desire scale and robot waiter usage attitude scale, and by Hwang et al., (2019b) for WOM scale were benefited. All 3 scales consist of 3 items.

The study was carried out with the data obtained using the online survey method. The survey form link was shared on social media platforms and the people who shared it were asked to share it with others. Before filling out the questionnaire, it was requested to watch a video containing the services provided by the robot waiters in a restaurant. Participants filled out the questionnaire after watching the video.

Ethics committee approval of this study was obtained by Van Yüzüncü Y1l University Social and Human Sciences Ethics Committee on 08.11.2021 with the decision numbered 2021/17-04.

\subsection{Universe and Sample}

While the population of the study consists of people living in Turkey, the sample consists of 316 people. There are 2 independent variables in the research model. Accordingly, the sample size of 316 fulfills Tabachnick and Fidell's (2007: 123) sample size condition of $\mathrm{N}>50+8 \mathrm{M}$ (M=number of 
independent variables) and Stevens' (1996: 72) sample size of at least 15 participants per independent variable. The sample of the study was reached by snowball sampling method.

Demographic information about the participants is given in Table 1.

Table 1. Demographic information about the participants

\begin{tabular}{|l|l|c|}
\hline Gender & Frequency & Percentage (\%) \\
\hline Female & 137 & 43.4 \\
\hline Male & 179 & 56.6 \\
\hline Age & Frequency & Percentage (\%) \\
\hline $9-25$ & 104 & 32.9 \\
\hline $26-40$ & 164 & 51.9 \\
\hline $41-56$ & 41 & 13 \\
\hline $57-75$ & 7 & 2.2 \\
\hline Monthly Income & Frequency & Percentage (\%) \\
\hline $0-2500$ TL & 108 & 34.2 \\
\hline $2501-5000$ TL & 75 & 23.7 \\
\hline $5001-7500$ TL & 62 & 19.6 \\
\hline 7501 TL and more & 71 & 22.5 \\
\hline Educational Status & Frequency & Percentage (\%) \\
\hline Primary School & 7 & 2.2 \\
\hline Secondary School & 8 & 22.5 \\
\hline High School & 71 & 72.8 \\
\hline University & 230 & \\
\hline & & \\
\hline & & \\
\hline
\end{tabular}

\subsection{Validity and Reliability Analyses}

The exploratory factor and reliability analysis results are given in Table 2.

Table 2. Results of Exploratory Factor and Reliability Analyses

\begin{tabular}{|c|c|c|c|c|}
\hline Factor Name & $\begin{array}{l}\text { Factor } \\
\text { Expressions }\end{array}$ & Factor Load & Explained Variance \% & Reliability \\
\hline \multirow{3}{*}{ Usage Desire } & Desire2 & .974 & \multirow{3}{*}{73.648} & \multirow{3}{*}{.939} \\
\hline & Desire3 & .838 & & \\
\hline & Desire1 & .791 & & \\
\hline \multirow{3}{*}{ Usage Attitude } & Attitude1 & .916 & \multirow{3}{*}{7.36} & \multirow{3}{*}{.937} \\
\hline & Attitude2 & .875 & & \\
\hline & Attitude3 & .831 & & \\
\hline \multirow{3}{*}{ WOM } & WOM3 & .937 & \multirow{3}{*}{5.517} & \multirow{3}{*}{.877} \\
\hline & WOM2 & .810 & & \\
\hline & WOM1 & .711 & & \\
\hline \multicolumn{2}{|c|}{ Total Variance Explained \% } & \multicolumn{3}{|r|}{86.525} \\
\hline \multicolumn{3}{|c|}{ Kaiser-Meyer-Olkin (KMO) Meas. of Sampling Ade. } & \multicolumn{2}{|r|}{.934} \\
\hline \multirow{3}{*}{\multicolumn{3}{|c|}{ Bartlett's Test of Sphericity }} & Approx. Chi-Square & 2875.227 \\
\hline & & & Df & 36 \\
\hline & & & $\mathbf{P}$ & .000 \\
\hline
\end{tabular}


Cronbach's Alpha values of 0.939 for the scale of robot waiter usage desire in restaurants used in the study, 0.937 for the scale of robot waiter usage attitude in restaurants, and 0.877 for the WOM scale were reached. Accordingly, the scale has sufficient reliability.

The Kaiser-Meyer-Olkin (KMO) value and the Barlett Test of Sphericity were examined to understand whether the sample size was sufficient for factor analysis. It was observed that the KMO value was 0.934 and the Barlett Test of Sphericity gave significant results $\left(\chi^{2}(36)=2875.227\right.$; $\mathrm{p}<0.001)$. According to these values, it was understood that the data set was suitable for Exploratory Factor Analysis.

The factor structure of the scale was determined by using the Direct Oblimin method, which is one of the principal components analysis and oblique rotation methods. As a result of these processes, a structure with 3 factors has been reached, which explains $86.525 \%$ of the total variance. It was determined that each of the sub-factors explained more than $5 \%$ of the total variance.

When the path diagram for the confirmatory factor analysis results was examined, it was seen that the standardized values were below 1 . The fit values for confirmatory factor analysis are given in Table 3.

Table 3. Fit Indeces for Confirmatory Factor Analysis

\begin{tabular}{lcccccc}
\hline$\chi^{\mathbf{2}}$ & $\mathbf{S d}$ & $\mathbf{p}$ & $\chi^{\mathbf{2} / \mathbf{S d}}$ & GFI & CFI & RMSEA \\
\hline 45.203 & 24 & .006 & 1.883 & .971 & .993 & .053
\end{tabular}

As a result of the confirmatory factor analysis, standardized factor loads of the items and the AVE and CR values of the factors are given in Table 4.

Table 4. Standard Regression Coefficients of the Items and AVE and CR Values of the Factors

\begin{tabular}{|c|c|c|c|}
\hline Items & Desire & Attitude & WOM \\
\hline With a strong passion, I would like to use a robot waiter in a restaurant. & 0.96 & & \\
\hline I would like to use a robot waiter in a restaurant. & 0.86 & & \\
\hline I desire the use of a robot waiter in a restaurant. & 0.92 & & \\
\hline I will be welcome the use of a robot waiter in a restaurant. & & 0.89 & \\
\hline I am positive about the use of robot waiters in a restaurant. & & 0.93 & \\
\hline I will be pleasing the use of a robot waiter in a restaurant. & & 0.92 & \\
\hline I can encourage restaurants that use robot waiters to others. & & & 0.86 \\
\hline I can recommend restaurants that use robot waiters. & & & 0.85 \\
\hline I can say positive things about the use of robot waiters in the restaurant. & & & 0.81 \\
\hline$\overline{A V E}$ & 0.63 & $\mathbf{0 . 6 3}$ & $\mathbf{0 . 5 3}$ \\
\hline $\mathbf{C R}$ & 0.94 & 0.94 & 0.88 \\
\hline
\end{tabular}


To ensure convergent validity, all CR values on the scale should be greater than AVE values and AVE values should be greater than 0.5. For this, each factor structure is evaluated separately, independently of each other (Yaşlığlu, 2017: 82). When the factor structures in the scale are examined, it is seen that the AVE value of each factor is greater than 0.5 and the CR values are greater than the AVE values. Therefore, convergent validity was achieved.

According to the results of explanatory and confirmatory factor analysis, the construct validity of the scale was ensured.

\subsection{Analysis of Data and Findings}

Structural equation modeling was used in the analysis of the data. IBM SPSS AMOS24 program was used for analysis. The fit indices of the model are given in Table 5.

Table 5. Model Fit Indices

\begin{tabular}{lcccc}
\hline Fit Indices & Perfect Fit & Acceptable Fit & $\begin{array}{c}\text { Model Fit } \\
\text { Summary }\end{array}$ & Results \\
\hline$\chi 2 /$ Sd $(45,203 / 24)$ & \multicolumn{2}{c}{$\leq$} & 1.883 & Perfect Fit \\
RMSEA & $0 \leq$ RMSEA $\leq 0.05$ & $0.05 \leq$ RMSEA $\leq 0.10$ & 0.053 & Acceptable Fit \\
SRMR & $0 \leq \mathrm{SRMR}<0.05$ & $0.05 \leq \mathrm{SRMR} \leq 0.10$ & 0.017 & Perfect Fit \\
GFI & $0.95 \leq \mathrm{GFI} \leq 1$ & $0.90 \leq \mathrm{GFI} \leq 0.95$ & 0.971 & Perfect Fit \\
AGFI & $0.90 \leq \mathrm{AGFI} \leq 1$ & $0.85 \leq \mathrm{AGFI} \leq 0.90$ & 0.945 & Perfect Fit \\
CFI & $0.95 \leq \mathrm{CFI} \leq 1$ & $0.90 \leq \mathrm{CFI} \leq 0.95$ & 0.993 & Perfect Fit \\
NFI & $0.95 \leq \mathrm{NFI} \leq 1$ & $0.90 \leq \mathrm{NFI} \leq 0.95$ & 0.984 & Perfect Fit \\
TLI & $0.95 \leq \mathrm{TLI} \leq 1$ & $0.90 \leq \mathrm{TLI} \leq 0.95$ & 0.989 & Perfect Fit \\
\hline
\end{tabular}

When the results of the analysis are examined, it is seen that the fit indices of the model are acceptable. According to the results of the analysis, it is seen that the acceptable fit index $(\chi 2 / \mathrm{sd}=$ 1.883 ) is less than 5 and has a statistically sufficient index. RMSEA: 0.053; SRMR: 0.017; GFI: 0.971; AGFI: 0.945; CFI: 0.993; NFI: 0.984 and TLI: 0.989 indices were reached and it was understood that these indices were at a good level.

Table 6. Structural Equation Modeling Results

\begin{tabular}{ccccccc}
\hline Variables & $\begin{array}{c}\text { Standardized RG } \\
\text { COEFF }(\boldsymbol{\beta})\end{array}$ & $\begin{array}{c}\text { Critic Ratio } \\
\text { (C.R.) }\end{array}$ & $\mathbf{R}^{2}$ & $\mathbf{P}$ & $\begin{array}{c}\text { Hypotheses } \\
\text { Hypothesis } \\
\text { Results }\end{array}$ \\
\hline Attitude<---Desire & 0.823 & 18.442 & 0.678 & $* * *$ & $\mathrm{H}_{1}$ & Accepted \\
WOM<---Desire & 0.573 & 7.970 & 0.838 & $* * *$ & $\mathrm{H}_{2}$ & Accepted \\
WOM<---Attitude & 0.421 & 6.304 & 0.838 & $* * *$ & $\mathrm{H}_{3}$ & Accepted \\
\hline
\end{tabular}

When Table 6 is examined, it is seen that the desire to use robots in restaurants has a direct, positive and significant effect on the attitude to use robots $(\beta=0.823 ; p<0.05)$. When we look at the effect of the desire to use robots on WOM in restaurants, it is understood that there is a direct, positive 
and significant effect $(\beta=0.573 ; \mathrm{p}<0.05)$. It has been observed that the attitude of using robots in restaurants has a direct, positive and significant effect on $\operatorname{WOM}(\beta=0.421 ; \mathrm{p}<0.05)$.

Table 7. Indirect Effect Results of the Study

\begin{tabular}{ccccc}
\hline Variables & $\begin{array}{l}\text { Standardized } \\
\text { Indirect Effect }(\boldsymbol{\beta})\end{array}$ & $\begin{array}{l}\text { Bootstrap(Lower } \\
\text { Bounds/Upper Bounds) \%95 CI }\end{array}$ & $\begin{array}{c}\text { Hyp. } \\
\text { Hyp. } \\
\text { Results }\end{array}$ \\
\hline WOM<---Attitude<---Desire & 0.347 & $0.200-0.516$ & $\mathrm{H}_{4}$ & Accepted \\
\hline
\end{tabular}

Note: Bootstrap resampling $=5000$.

According to Bootstrap results in Table 7, there is an indirect, positive and significant effect when considering the mediating role of robot usage attitude between the desire to use robots and WOM in restaurants $(\beta=0.347,95 \%$ CI $[0.200-0.516])$.

\section{CONCLUSION, DISCUSSION AND RECOMMENDATIONS}

Technology, which has dramatic effects in almost every aspect of all areas of life, shows itself strongly in the food and beverage sector. The robot waiter technology, which has started to be used in some countries, is expected to be used both in more countries and more widely in the future. Among the reasons for this expectation, robot waiters can be produced cheaper in the future and the sales price decreases, more advanced technological features can be added to robot waiters, so these robots can be used more effectively and efficiently, and decrease human-induced service failures.

According to the results obtained from the study, it was seen that the desire to use a robot waiter in restaurants has a direct, indirect (through the attitude towards using a robot waiter) and positive effect on WOM. WOM has very important advantages for companies such as having a strong effect on purchasing behavior (Kotler et al., 2018: 163), creating, developing and maintaining customer relations (Pride and Ferrell, 2019: 290), and being effective in positioning the brand (Dibb and Simkin, 2013: 214). Considering these advantages, it will be easily understood how important it is to gain people's desire to use a robot waiter. According to another result obtained from the study, the desire to use robot waiters in restaurants has a direct positive effect on customers' attitude to use robot waiters. The most important reason for companies working in the food and beverage sector to employ robot waiters is to get more customers. It will not be a surprise that customers, whose attitude towards robot waiter usage is positively affected, prefer food and beverage companies that employ robot waiters. From this point of view, it will be again understood how important it is for people to acquire the desire to use a robot waiter.

In the study, it was seen that the attitude of using robot waiters in restaurants has a direct positive effect on WOM. This result is similar to the studies of Foroudi et al., (2021), Jalilvand et al., (2012), Baber et al., (2016) and Albarq (2014) in terms of the effect of attitude on WOM. The result that the desire to use robot waiters in restaurants has a positive effect on the attitude of using robot 
waiters (when considered in the context of desire and attitude) shows parallelism with the works, which Hwang et al., (2019a), Hwang and Lyu (2020), Kang and Kim (2012) and Hwang et al., ( 2020b). Another result obtained in the study, that the desire to use robot waiters in restaurants has a positive effect on WOM (When considered in the context of desire and WOM), which coincides with the results of Hennig-Thurau et al., (2004), Lee et al., (2013) and Parry et al., (2021).

According to the results of the study, it has been seen that increasing the desire to use robot waiters of humans is very important for companies. For this, it is very important to use marketing communication activities effectively. Because, according to the AIDA model, which is one of the recommended models for an effective communication activity, people's desire for a product must be formed before they can act. Before the desire for the product, the attention and interest of the consumers should be drawn (Blythe, 2006: 19). Especially children are more interested in robot waiters (Yazıcı Ayyıldız and Eroğlu, 2021: 1113-1114). Accordingly, in the marketing communication efforts to be made, besides making content that will attract the attention of children, cartoon channels, children's programs, internet games that children frequently play, suitable times to reach children through communication, etc., choosing the places and times where children can be reached will increase the effectiveness of marketing communication activities. In addition, adding more features to the robot waiters that will attract the attention of children will both attract more attention in marketing communication activities and cause consumers to prefer restaurants with more interesting robots.

In the study, the effects of robot waiter usage desire on robot waiter usage attitude and WOM were investigated. In other studies, using the same variables, it can be investigated whether there is a difference in terms of demographic characteristics. Studies can be conducted with other variables such as functionality and hedonic motivation related to robot waiters.

The robot waiter product, which is one of the innovations in the food and beverage sector, was used in the study. In other studies, consumer behavior towards other products, such as a robot cook, could be investigated.

In the study, the effect of robot technology on consumers in the food and beverage sector was investigated. In other studies, the effect of robot technologies used in other sectors such as airlines on consumers can be investigated.

\section{REFERENCES}

Albarq, A. N. (2014). Measuring the Impacts of Online Word-Of-Mouth on Tourists' Attitude and Intentions To Visit Jordan: An Empirical Study. International Business Research, 7(1), 14-22. 
Asif, M., Sabeel, M., Mujeeb-ur Rahman, K. Z. (2015). Waiter Robot-Solution to Restaurant Automation. In Proceedings of the 1st student multi disciplinary research conference (MDSRC), At Wah, Pakistan.

Baber, A., Thurasamy, R., Malik, M. I., Sadiq, B., Islam, S., Sajjad, M. (2016). Online word-of-mouth Antecedents, Attitude and Intention-to-Purchase Electronic Products in Pakistan. Telematics and Informatics, 33(2), 388-400.

Blythe, J. (2006). Essentials of Marketing Communications. Edinburgh: Pearson Education Limited.

Breckler, S. J., Wiggins, E. C. (1989). On Defining Attitude and Attitude Theory: Once More with Feeling (407-427). Attitude Structure and Function. Ed. Anthony R. Pratkanis, Steven J. Breckler ve Anthony G. Greenwald. Psychology Press.

Dibb, S., Simkin, L. (2013). Marketing Essentials. United Kingdom: Cengage Learning.

Dülek, B.,Aydın, İ. (2020). Effect of Social Media Marketing On E-Wom, Brand Loyalty, and Purchase Intent. Bingöl Üniversitesi Sosyal Bilimler Enstitüsü Dergisi, (20), 271-288.

Fill,C., Turnbull, S. (2016). Marketing Communications Discovery, Creation and Conversations. Harlow: Pearson Education Limited

Foroudi, P., Palazzo, M., Sultana, A. (2021). Linking Brand Attitude to Word-Of-Mouth and Revisit Intentions in the Restaurant Sector. British Food Journal, 123(13), 221-240.

Garcia-Haro, J. M., Oña, E. D., Hernandez-Vicen, J., Martinez, S., Balaguer, C. (2021). Service Robots in Catering Applications: A Review and Future Challenges. Electronics, 10(1), 1-22.

Grewal, D., Levy, M. (2017). Marketing. New York: McGraw-Hill Education.

Gruen, T. W., Osmonbekov, T., Czaplewski, A. J. (2006). eWOM: The Impact of Customer-toCustomer Online Know-How Exchange on Customer Value and Loyalty. Journal of Business Research, 59(4), 449-456.

Hamdany, A. H. S., Albak, L. H., Al-Nima, R. R. O. (2019). Wireless Waiter Robot. TEST Engineering \& Management, The Mattingley Publishing Co., Inc, 81, 2486-2494.

Hennig-Thurau, T., Gwinner, K. P., Walsh, G., Gremler, D. D. (2004). Electronic Word-Of-Mouth Via Consumer-Opinion Platforms: What Motivates Consumers to Articulate Themselves on the Internet?. Journal of Interactive Marketing, 18(1), 38-52.

Hospitality \& Catering news. (2019). Robot Waiters, It's Happening Now and Coming to a Restaurant Near You Soon. https://www.hospitalityandcateringnews.com/2019/09/robot-waitershappening-now-coming-restaurant-nearsoon/ Erişim Tarihi: 21.10.2021 
Hwang, J., Kim, H., Kim, W. (2019a). Investigating Motivated Consumer Innovativeness in the Context of Drone Food Delivery Services. Journal of Hospitality and Tourism Management, 38, $102-110$.

Hwang, J., Lee, J. S., Kim, H. (2019b). Perceived Innovativeness of Drone Food Delivery Services and Its Impacts on Attitude and Behavioral Intentions: The Moderating Role of Gender and Age. International Journal of Hospitality Management, 81, 94-103.

Hwang, J., Park, S., Kim, I. (2020a). Understanding Motivated Consumer Innovativeness in the Context of a Robotic Restaurant: The Moderating Role of Product Knowledge. Journal of Hospitality and Tourism Management, 44, 272-282.

Hwang, J., Lee, K. W., Kim, D., Kim, I. (2020b). Robotic Restaurant Marketing Strategies in the Era of the Fourth Industrial Revolution: Focusing on Perceived Innovativeness. Sustainability, 12(21), 1-12.

Hwang, J., Lyu, S. O. (2020). Relationships Among Green Image, Consumer Attitudes, Desire, and Customer Citizenship Behavior in the Airline industry. International Journal of Sustainable Transportation, 14(6), 437-447.

Hwang, J., Kim, H., Kim, J. J., Kim, I. (2021). Investigation of Perceived Risks and Their Outcome Variables in the Context of Robotic Restaurants. Journal of Travel \& Tourism Marketing, 38(3), 263-281.

Ivanov, S. H., Webster, C., Berezina, K. (2017). Adoption of Robots and Service Automation by Tourism and Hospitality Companies. Revista Turismo \& Desenvolvimento, 27(28), 1501-1517.

Jalilvand, M. R., Samiei, N., Dini, B., Manzari, P. Y. (2012). Examining the Structural Relationships of Electronic Word Of Mouth, Destination Image, Tourist Attitude Toward Destination and Travel Intention: An Integrated Approach. Journal of Destination Marketing \& Management, 1(1-2), 134-143.

Kang, J. Y. M., Kim, E. (2012). e-Mass Customisation Apparel Shopping: Effects of Desire for Unique Consumer Products and Perceived Risk on Purchase Intentions. International Journal of Fashion Design, Technology and Education, 5(2), 91-103.

Kapoor, R., Madichie, N. (2012). Consumer Behaviour: Text and Cases: Text and Cases. Noida: Tata McGraw-Hill,.

Kerin, R. A., Hartley, S. W. (2017). Marketing. New York: McGraw-Hill.

Kotler, P. Armstrong, G., Opresnik, M.O. (2018). Principles of Marketing. Pearson Education Limited. 
Lee, S. H., Noh, S. E., Kim, H. W. (2013). A Mixed Methods Approach to Electronic Word-Of-Mouth in the Open-Market Context. International Journal of Information Management, 33(4), 687696.

LondonlovesBusiness. (2019). London Restaurant Chain Becomes First in the UK and Europe to Hire a Robotic Waitress. https://londonlovesbusiness.com/london-restaurant-chainbecomes-first-inthe-uk-and-europe-to-hire-a-roboticwaitress Erişim Tarihi: 21.10.2021

Parry, M. E., Yang, X., Takemura, M. (2021). The Impact of Social Motivations on Word-of-Mouth Generation by Japanese Consumers. Journal of International Consumer Marketing, 33(2), 115136.

Perugini, M., Bagozzi, R. P. (2004). The Distinction Between Desires and Intentions. European Journal of Social Psychology, 34(1), 69-84.

Pride, W. M., Ferrell, O. C. (2019). Foundations of Marketing. Boston: Cengage Learning Inc.

Stevens, J. (1996). Applied Multivariate Statistics for the Social Sciences. Mahwah, NJ: Lawrence Erlbaum.

Tabachnick, B. G., Fidell, L. S. (2007). Using Multivariate Statistics. Boston: Pearson Education.

Wen-Hai, C., Yuan, C. Y., Liu, M. T., Fang, J. F. (2019). The effects of outward and inward negative emotions on consumers' desire for revenge and negative word of mouth. Online Information Review, 43(5), 818-841.

Yaşlığlu, M. M. (2017). Sosyal Bilimlerde Faktör Analizi ve Geçerlilik: Keşfedici ve Doğrulayıcı Faktör Analizlerinin Kullanılması. İstanbul Üniversitesi İşletme Fakültesi Dergisi, 46, 74-85.

Yazıcı Ayyıldız, A., Eroğlu, E. (2021). Restoranlarda Kullanılan Akıllı Teknolojiler ve Robot Restoranlar Hakkında Tripadvisor'da Yapılan Yorumların Değerlendirilmesi. Journal of Tourism and Gastronomy Studies, 9(2), 1102-1122. 